\title{
Multiparametric Atomic Force Microscopy Identifies Multiple Structural and Physical Heterogeneities on the Surface of Trypanosoma brucei
}

Claire Valotteau ${ }^{1 *}$, Andra C. Dumitru $^{1 *}$, Laurence Lecordier ${ }^{2}$, David Alsteens ${ }^{1}$, Etienne Pays ${ }^{2}$, David Pérez-Morga ${ }^{2 * *}$ and Yves F. Dufrêne ${ }^{1,3^{* *}}$

${ }^{1}$ Louvain Institute of Biomolecular Science and Technology, UCLouvain, Croix du Sud, 4-5, bte L7.07.07., B-1348 Louvain-la-Neuve, Belgium

${ }^{2}$ Laboratory of Molecular Parasitology, IBMM, Université Libre de Bruxelles, 12 rue des professeurs Jeener et Brachet, B-6041 Gosselies, Belgium

${ }^{3}$ Walloon Excellence in Life sciences and Biotechnology (WELBIO), B-1300 Wavre, Belgium

${ }^{*} \mathrm{CV}$ and $\mathrm{ACD}$ contributed equally

${ }^{* *}$ Corresponding authors:

Yves Dufrêne <yves.dufrene@uclouvain.be>

David.Perez-Morga@ulb.ac.be 


\section{Supplementary figures}
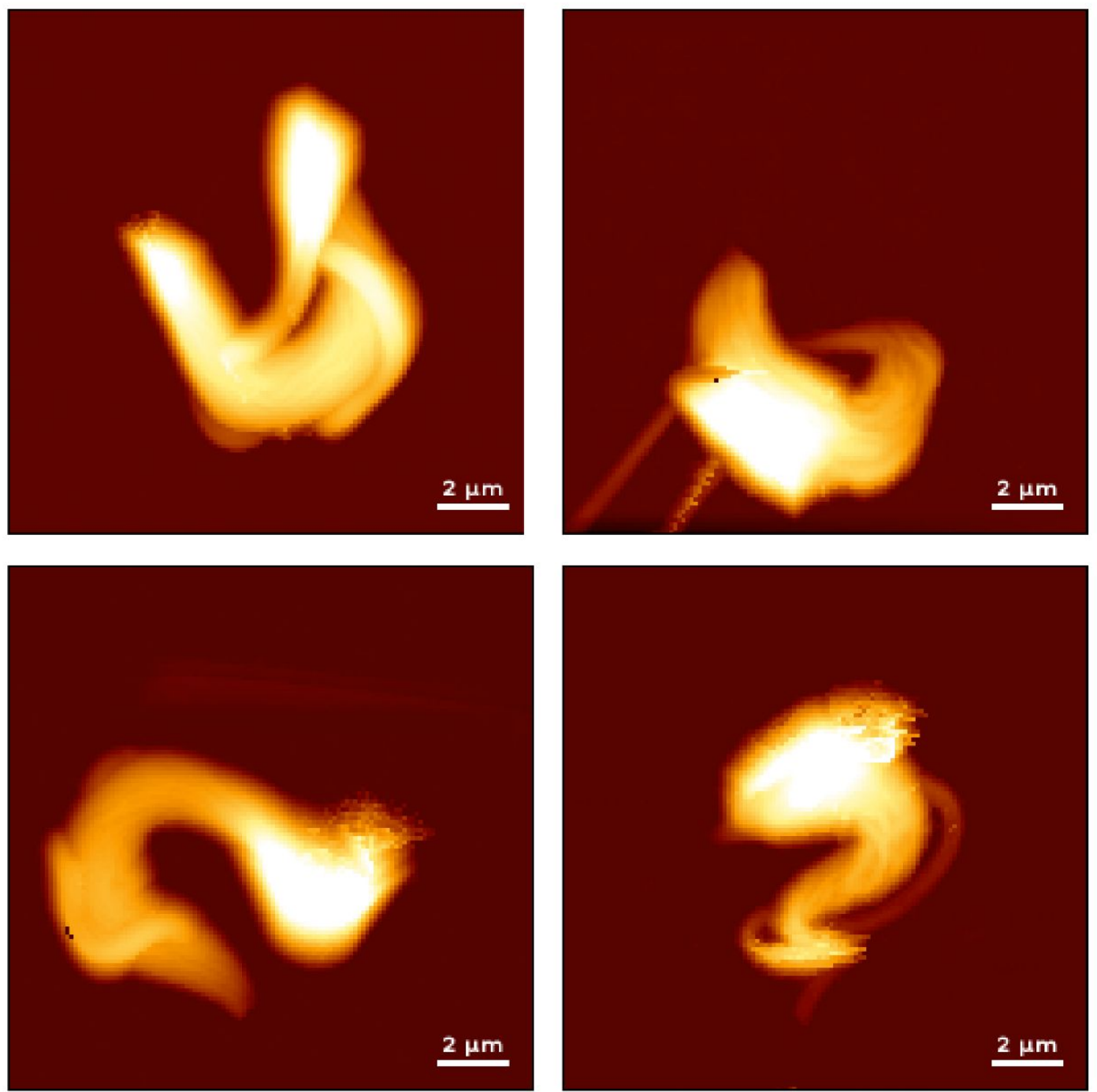

Figure S1. Imaging chemically-fixed T. brucei cells. Additional AFM height images of four independent strongly-fixed cells recorded in PBS buffer (color scale: $4 \mu \mathrm{m}$ ). 

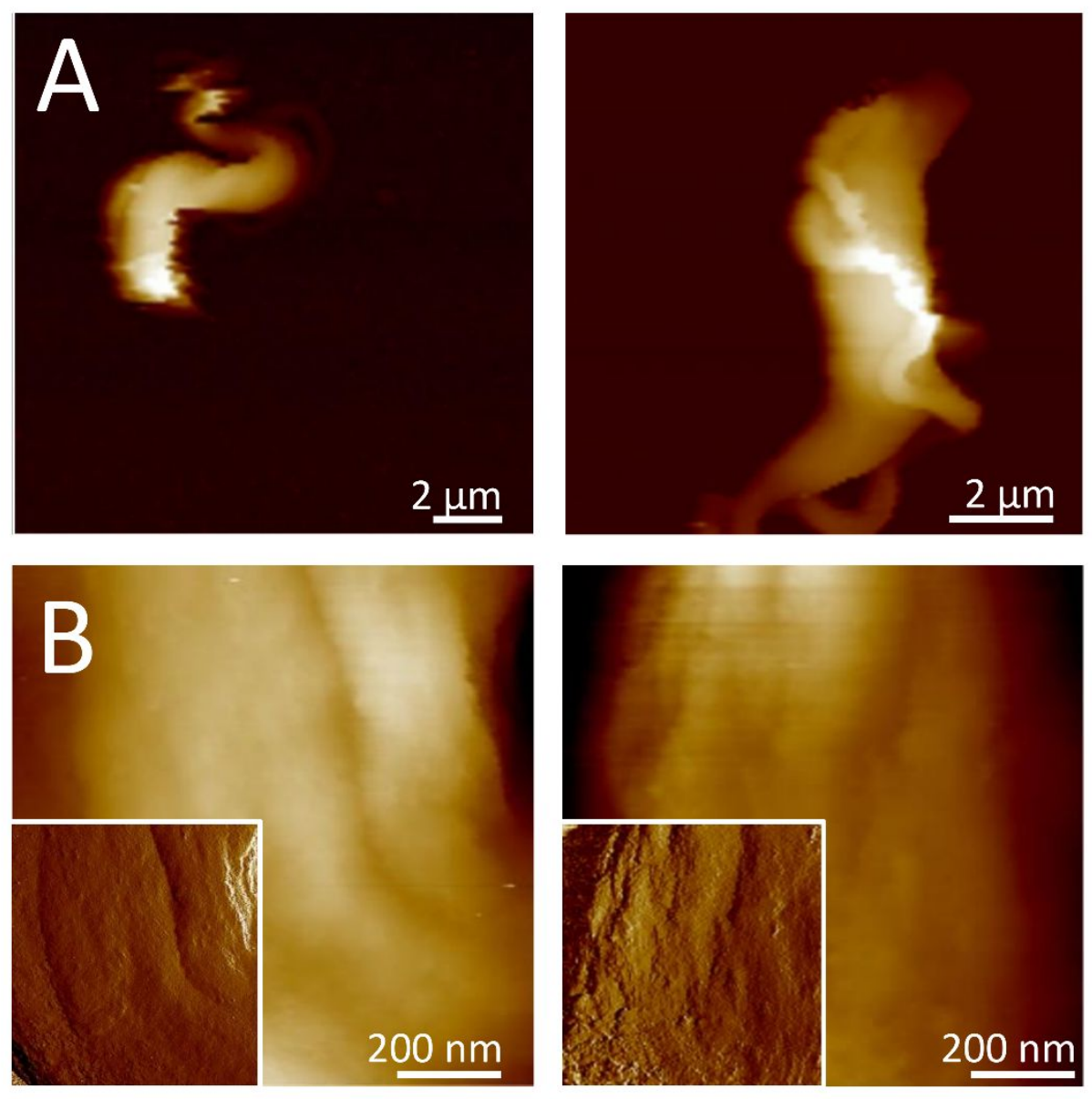

Figure S2. Imaging the $T$. brucei cell surface under minimally-invasive conditions.

(A) Additional height images of two different lightly-fixed cells recorded in PBS buffer.

(B) High-resolution height images (color scale: $200 \mathrm{~nm}$ ) recorded on two different cells, together with the corresponding error images (insets). 